\title{
FESTEJOS DO CATOLICISMO TRADICIONAL NO INTERIOR DO BRASIL
}

\author{
Marcelo Leles Romarco de Oliveira \\ Evanize Kelli Siviero Romarco
}

Discutem-se alguns festejos católicos tradicionais em comunidades rurais do Brasil, com base em material coletado através de entrevistas semiestruturadas e impressões de campo no Amapá e em Goiás. Focalizam-se principalmente as festas do Divino Espírito Santo e dos santos padroeiros dessas comunidades, abordando os seus desdobramentos e a sua importância cultural e simbólica para aqueles que as praticam. Destacam-se danças como a catira, praticada em Goiás, e o marabaixo, cultivado por comunidades quilombolas do Amapá. Foi possivvel apreender que, apesar da modernidade, esses festejos perduram como importante manifestação sociocultural desses grupos. [Abstract on page 244]

FESTEJOS RELIGIOSOS, FOLIA, DANÇAS CIRCULARES. 


\section{INTRODUÇÃO}

Este estudo apresenta reflexões sobre algumas manifestações culturais encontradas no interior do Brasil, mais especificamente na zona rural de dois estados brasileiros, Goiás e Amapá. O material em que se apoia foi coletado em conversas com moradores das comunidades visitadas e na observação dos festejos religiosos praticados por esses atores sociais.

Segundo Ferlini (2001), homenagens ou cultos às divindades protetoras estão na origem das festas portuguesas, que foram introduzidas no Brasil a partir da colonização, e mantêm, ainda, forte influência em comunidades tradicionais no interior do país, servindo, aliás, como elo com outros espaços e atores.

Através de entrevistas semiestruturadas e impressões de campo, foi possível refletir sobre esses festejos como importantes manifestações culturais encontradas em comunidades rurais do interior dos estados visitados. É importante destacar que em algumas situações os pesquisadores acompanharam os preparativos dos festejos e participaram de alguns dos rituais que os integram, como no caso da folia do Divino Espírito Santo em assentamentos rurais, na região Pé de Serra, no município de Padre Bernardo, no Estado de Goiás. Essa vivência permitiu maior compreensão de alguns relevantes elementos simbólicos e culturais, como danças, músicas, cantigas, queimas de fogos, representações emblemáticas do sagrado que, segundo Gaeta (1997), são consentidas e incentivadas pelo catolicismo tradicional, como privilegiadoras dos sinais visíveis da fé e de graças alcançadas.

De acordo com Saraiva e Silva (2008), esses eventos em algumas comunidades também são responsáveis pelo estabelecimento do calendário de festividades que reúnem as comunidades para celebrar, agradecer ou pedir proteção ao santo devocionário.

Assim, essas festas incluem muita fé, atos religiosos, danças e produção de comidas típicas, entre outros aspectos. As famílias entrevistadas declararam que nessa época os povoados ou comunidades rurais que realizam essas festas são mais visitados por parentes e amigos moradores das áreas urbanas das cidades e de outras localidades.

Nesse contexto é possível citar os festejos religiosos do catolicismo tradicional, como as folias, que são importantes para a integração desses grupos. São marcadas por foliões que cantam pedindo a benção das divindade e acompanham o alferes até o local do cruzeiro para, em seguida, montar seus animais e sair para o demorado giro, cada folia numa direção. Durante o giro, os foliões devem preparar as cantigas de rodas e catiras que vão cantar e dançar nas casas visitadas e em que a folia pernoita.

Essas danças e ladainhas, como hoje as conhecemos, trazem em suas raízes o passado longínquo, a ancestralidade dos povos de caráter comunitário e gregário - que praticam dança e o canto como comunhão e transcendência. Relembram, como cita Garaudy (1980), um tempo em que dançar e cantar eram celebrações, participações, encontros e reafirmações dos ciclos da vida na tensão entre o humano e o divino. 
Autores como Brandão (1980) e Prado (1977) consideram esse tipo de manifestação momentos especiais que têm o papel, por exemplo, de reconstruir os limites de uma comunidade, reunindo serus membros e mancando seu pertencimento mediante a vivência e partilha de valores e crenças.

\section{OS FESTEJOS RELIGIOSOS COMO EXPRESSÃO CULTURAL DAS ZONAS RURAIS BRASILEIRAS}

Os dados aqui apresentados referem-se à festa do Divino Espírito Santo em duas regiões, a primeira incluindo dois assentamentos rurais no interior do Estado de Goiás, e a outra representada por comunidades quilombolas da região sul do Estado do Amapá. Apesar da semelhança dos rituais, é possível destacar algumas características peculiares nessas festas, sobretudo em relação à comida e às danças praticadas normalmente no final do festejo, como a catira em Goiás e o marabaixo ${ }^{1}$ em comunidades quilombolas do Amapá.

É importante destacar que essas festas, além do cunho de fé e religiosidade, são marcadas por diversas manifestações culturais materiais e imateriais, como, por exemplo, bandeira, comidas típicas, altares, danças e rituais, como o "correr os pousos". ${ }^{2}$ Além disso, esses festejos exprimem, também, as relações de reciprocidade, que vão caracterizar muitas comunidades rurais brasileiras.

Nesse sentido, Brandão (1981) aponta que uma das características marcantes das populações rurais é a fé em Deus e nos santos, o que justifica a importância das festas religiosas na organização social desses grupos, integrando-os, mas também o próprio município em que se inserem essas comunidades.

No município de Macapá-AP, um festival reúne e congrega grupos de marabaixo de todo o estado, possibilitando que eles se apresentem fora de suas comunidades nas épocas dos festejos religiosos - períodos de integração e oportunidade de visibilidade para os grupos culturais nas festas dos santos padroeiros das comunidades ou até mesmo do município.

Segundo os relatos dos atores entrevistados nessa época de grandes encontros dos grupos, tanto as comunidades se voltam para esses festejos quanto os moradores da sede dos municípios se comprometem com essas celebrações. Em alguns casos, o ápice do festejo é o encontro das folias que circulam na zona rural e que são recebidas com festa e comemoração pelos moradores das cidades, ansiosos por esse momento.

Candido (1987) ao estudar comunidades rurais no interior do Estado de São Paulo demonstra que nessas localidades as festas despertam o espírito de ajuda mútua, um dos elementos de definição da solidariedade vicinal, que liga pessoas e espaços. Para concretizá-las, essas atividades acontecem em meio a complexo conjunto de relações que ultrapassam o espaço familiar, chegando a abranger em diversas situações outras co- 
munidades, o que define a marca de um grupo ou de vários grupos, criando, assim, uma identidade cultural dessas localidades.

A folia de reis e do Divino Espírito Santo e as homenagens aos santos padroeiros das cidades e a Santo Antônio, São João e São Benedito, entre outros, são as festas religiosas mais comuns nessas regiões, quase sempre incluindo em seus rituais ladainhas, cânticos, pagamento de promessas ou oferecimento de prece, missa ou queima de um pacote de velas.

Outro ponto a ser observado nas festas dos santos diz respeito às novenas, que conformam complexo ritual envolvendo reza, música, dança e confraternização. Acontecendo geralmente antes das festas, sua principal função é preparar os fiéis espiritualmente para o culto ao santo que será homenageado. São distribuídas ao longo de nove dias, de modo que a última noite caia na data da festa.

De acordo com depoimentos dos entrevistados, a 'noitada', cada um dos dias de uma novena, geralmente é patrocinada por uma ou mais famílias moradoras do sítio ou de alguma fazenda próxima, que se responsabilizam por providenciar a comida e a bebida a servir aos músicos que acompanham a reza numa capela local (quando existe) ou na casa de algum morador. O patrocínio de uma noitada normalmente confere muito prestígio social às famílias escolhidas. No sentido religioso, é nesse momento que a família como um todo recebe nominalmente as graças de seu santo de devoção.

Nesse sentido, Prado (1977) aponta que, a par do caráter festivo através das danças e comidas, as festas dos santos representam a maneira mais forte de se provocar seu milagre.

\section{A FOLIA DO DIVINO ESPÍRITO SANTO NOS ASSENTAMENTOS RURAIS NA REGIÃO PÉ DE SERRA EM GOIÁS}

A região Pé de Serra localizada no município de Padre Bernardo no Estado de Goiás, no entorno do Distrito Federal, é formada por cinco assentamentos rurais constituídos no final do século XX; a maioria dos assentados é de imigrantes vindos, sobretudo, das áreas rurais dos Estados de Goiás, Minas Gerais e do Nordeste brasileiro, formando, assim, um caldeirão cultural bastante diversificado.

Em comum, os assentados apresentam a característica de, antes de migrar para a região, ter trabalhado em Brasília, exercendo diversas atividades. Apesar de os assentamentos serem formados por população tão heterogênea, ainda assim é possível encontrar outros traços comuns nesse grupo, tendo como destaque a fé e as crenças nos santos de devoção, o que atesta ao local identidade cultural e simbólica marcada pela religiosidade.

Nesse sentido, nesses assentamentos, uma forma de expressar essa fé é através da comemoração da folia do Divino Espírito Santo, que é marcada, por um lado, pelo caráter religioso - novenas, ladainhas ou pagamento de promessas - e, por outro, pelo ritual profano. Realizada na casa da festeira, uma espécie de organizadora da folia. a festa, 
além de ser momento de celebração o é também de integração; vários assentados da região e convidados que moram na cidade vêm participar do evento, que chega às vezes a reunir cerca de 400 pessoas.

A festa do Divino Espírito Santo nos assentamentos dessa região começou em 2002, quando uma moradora do assentamento Vereda II, o maior deles, com mais de 150 famílias, resolveu organizar a folia. Nessa ocasião a maioria das famílias já ocupava suas terras. Segundo essa moradora, a ideia de organizar a folia surgiu logo após uma promessa feita ao Divino Espírito Santo para melhorar o estado de sua saúde que na ocasião apresentava quadro clínico grave. A promessa consistia em que, se houvesse melhora em seu estado de saúde, ela se responsabilizaria por organizar a folia nos assentamentos da região durante sete anos. A partir dessa promessa, a entrevistada relatou que sua melhora foi acontecendo e em pouco tempo saiu do hospital. Retornando ao assentamento ela resolveu pagar a promessa.

Eu fiz a promessa de organizar a folia e fazer a caminhada durante sete anos, mas eu pretendo fazer a festa até morrer. E espero que os meus filhos quando eu morrer continuem a festa (...) na primeira festa do Divino que aconteceu aqui a gente fez uma novena, levantou a bandeira, mas não foi feita a caminhada; isso já tem uns quatro anos. Mas a caminhada mesmo tem uns dois anos (festeira do assentamento Vereda II, 2006).

A festeira informa ter trazido essa tradição da festa do Divino Espírito Santo de Minas Gerais, estado de origem de seus familiares, onde diversas vezes ela presenciou a folia do Divino. Ainda segundo a entrevistada, no início, a realização da festa, além de representar o resgate de sua origem, também proporcionava união mais forte dos assentamentos e permitia que uma manifestação cultural tão importante para os católicos fosse perpetuada naquele novo espaço em formação. Outra expectativa da festeira era que a folia servisse para que os filhos dos assentados conhecessem esse tipo de rito e os estimulasse a realizá-lo todos os anos, tornando-se mais um elemento da identidade cultural daquela região.

Eu espero que depois dos sete anos que eu organizar a folia, outro devoto pegue a responsabilidade e que a folia sempre aconteça aqui, porque para nós, católicos, isso será muito importante (festeira do assentamento Vereda II, 2006).

Tendo a festa começado há pouco mais de quatro anos, apenas moradores de dois assentamentos estavam recebendo a folia. É importante destacar que sendo os assentamentos formados por sítios, as casas são distantes umas das outras, e a presença de assentados de outras religiões, que não recebem os foliões, influencia o raio de ação da folia.

Na ocasião da festa os pesquisadores acompanharam um trecho da folia, que ao todo percorreu mais ou menos 30 casas dos assentamentos Vereda II e Boa Vista. Segundo a festeira, a cada ano mais casas são visitadas, e sua esperança é que em breve todos os demais assentamentos recebam a folia. 


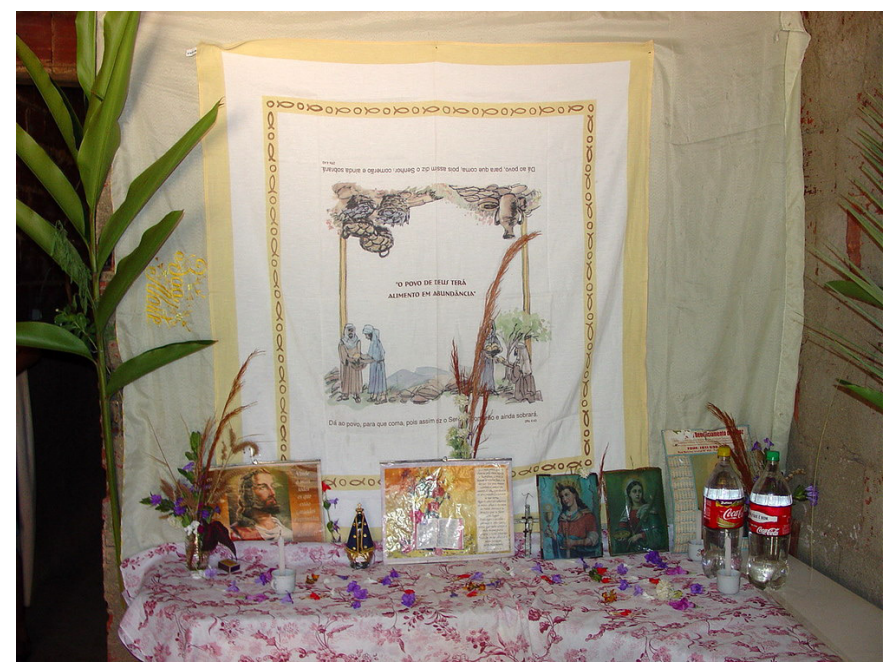

Figura 1: Altar na

casa de um devoto

Foto: Marcelo

Leles Romarco de

Oliveira

Para organizar a folia, ela conta com ajuda de outras famílias dos assentamentos, sobretudo daquelas de orientação católica, que têm fé no santo e por isso fazem questão de participar, tanto do ponto de vista da logística como fazendo doações de alimentos e dinheiro.

Brandão (1981) confirma essa organização ao informar que a folia decorre do trabalho ritual de um grupo consolidado que durante o período que antecede a festa arrecada contribuições para sua realização; em troca, a folia distribui bênçãos, auxilia no pagamento de promessas, atualiza a devoção ao Divino e contribui para a reunião de pessoas em refeições e no baile de encerramento. Trata-se, portanto, de empreendimento coletivo de assentados católicos e envolve vários outros assentados.

A rigor esse evento pode ser entendido, como classificou Mauss (2003), como um grande sistema de prestações totais, nos quais assentados e famílias são inscritos em corrente obrigatória em que bens de natureza econômica, social e religiosa são doados, recebidos e retribuídos.

Essas prestações e contraprestações se estabelecem de uma forma, sobretudo voluntária, por meio de regalos, presentes embora elas sejam no fundo rigorosamente obrigatórias, sob pena de guerra privada ou pública. Propusemos chamar tudo isso o sistema de prestações totais (MAUSS, 2003: 191).

De acordo com Brandão (1981), a folia tem importante papel no universo do camponês: seria um espaço simbolicamente reconstruído no tempo através de rituais que possibilitam a realização de trocas de bens e serviços entre um grupo fixo de moradores e um grupo de foliões.

No caso aqui em questão a folia ocupa espaços do cotidiano dos assentados, como as casas, as estradas e os atalhos. Quanto à trajetória, a folia é realizada a partir de uma lista feita pela festeira, que convida as famílias devotas do Divino, podendo tam- 


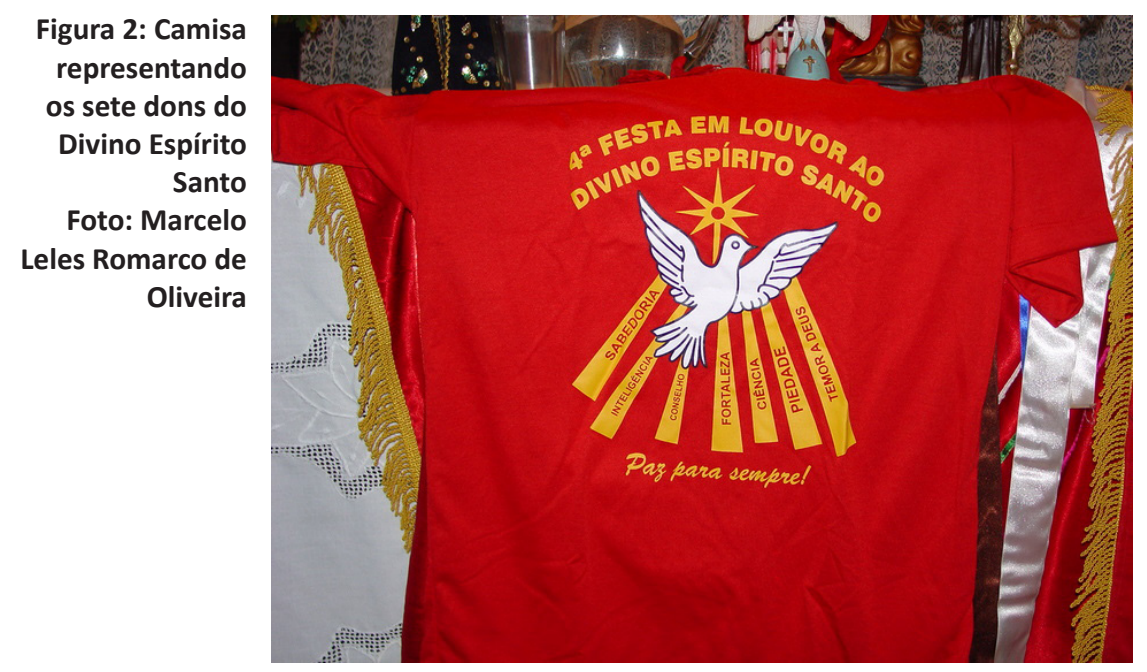

bém algum devoto entrar em contato com a festeira solicitando a presença da folia em sua casa.

Na região, a folia sai da casa da festeira, que fica no assentamento Vereda II. A jornada começa na alvorada rezando o terço e invocando saúde e proteção ao Divino Espírito Santo ou a outros santos de que os foliões são devotos. Isso ocorre num altar improvisado na casa da festeira. É importante ressaltar que em todas as casas que a folia visita também são improvisados altares, geralmente na sala, à porta da qual os foliões são recebidos e perguntam ao dono da casa se ele aceita a folia; aceitando, o dono da casa se ajoelha, beija a bandeira e convida a folia a entrar em sua casa; os foliões agradecem e entram então na casa, cantando e louvando.

Na casa, o proprietário oferece uma oferta, que no final é destinado para alguma igreja (...) essa celebração é importante porque também é uma evangelização. E cada família dá aquilo que pode, e não é obrigado a dar; mas praticamente todo mundo dá alguma coisa para o Divino (sr. JB, assentamento Boa Vista, 2006).

Às vezes, o dono da casa pede a bandeira e percorre todas as dependências da casa, abençoando. Cabe lembrar que um dos maiores símbolos da festa é a bandeira vermelha, com uma pomba branca de pés e bico vermelhos. $O$ vermelho significa o amor e o ardor missionário, e a pomba branca, o Espírito Santo. Além disso, na bandeira estão registrados os sete dons do Divino Espírito Santo, que são sabedoria, inteligência, conselho, fortaleza, ciência, piedade e temor a Deus. Esses dons, segundo a festeira, foram tirados da Bíblia, e, de acordo com um participante da folia, um caminho a buscar incluiria esses dons que o Divino representa (figuras 1 e 2 ).

Quanto à formação da folia, na região ela é constituída por: 
1- festeira: responsável por sua organização total. Nesse caso específico, é a festeira quem carrega a bandeira. Além disso, a folia sai de sua casa e para lá retorna no final do dia, momento em que a bandeira é hasteada, a pomba, solta, e a folia encerrada;

2- folião de guia: é aquele que vai puxando os cantos;

3- folião de contraguia: vai ajudando o folião guia; geralmente são dois;

4- intercessor: responsável por rezar o terço durante todo o trajeto;

5- tocadores: os que vão tocando bumbo, caixa e outros instrumentos;

Os que acompanham a folia são seus componentes, que ajudam na cantoria; é comum a folia ir aumentando à medida que vai passando nas casas.

Durante todo o percurso a intercessora continua rezando o terço em voz baixa, e os cantadores vão entoando cantigas saudando o Divino Espírito Santo. A folia vai seguindo a trajetória previamente acordada, ou seja, indo de casa em casa segundo o trajeto estabelecido para cumprir a jornada. De certa forma a folia da região tem esquema circular, como sinaliza a Figura 3.

A jornada aqui pode ser compreendida como um conjunto de visitas rituais às casas dos moradores dos assentamentos que são devotos. Segundo relatos dos entrevistados os foliões representam os apóstolos e são conduzidos às casas pelo alferes, abençoando as famílias e unindo-as em torno da celebração da festa que se aproxima. As rezas nas casas visitadas pela folia ajudam a reforçar o sentido de comunidade.

Devido ao fato de as distâncias serem muito grandes de uma casa a outra, a maior parte do trajeto é feita de camionete e caminhão, havendo também fiéis que acompanham a folia a cavalo.

Para Brandão (1981), a folia contribuiria para estabelecer um amplo ritual religioso por onde circularia um conjunto de dádivas entre um grupo de assentados cujas casas ela visita. Dessa forma a folia pode ser considerada um conjunto de rituais pelos quais os assentados se relacionam entre si e com o Divino Espírito Santo num amplo sistema de trocas - uma sequência de pedidos, ofertas e agradecimentos. Nesse sentido,

receber a folia em casa é muito bom, porque traz saúde, aumento de produção e fartura para a minha família (...) Já é dois anos que eu ofereço o almoço para os foliões (sr. A. assentamento Boa Vista, 2006).

Eu faço questão que a folia passe na minha casa, porque sempre dá proteção e bênção para toda a minha família (...) o que eu puder fazer para que a festa aconteça todos os anos eu vou fazer (sra. P. assentamento Vereda II).

Como já mencionado, na folia de 2006 foram visitadas aproximadamente 30 casas, incluindo a da festeira, todas de famílias católicas, envolvendo devotos dos assentamentos Vereda II e Boa Vista. Todos os moradores dos assentamentos da região são convidados para a festa de encerramento, católicos ou não, e os assentados de outras religiões acabam participando, como explicita o relato da festeira:

Aqui todo ano depois que é hasteada a bandeira e que a festa começa vem todo mundo, católico, crente, macumbeiro, quem vier será bem recebido (...) 


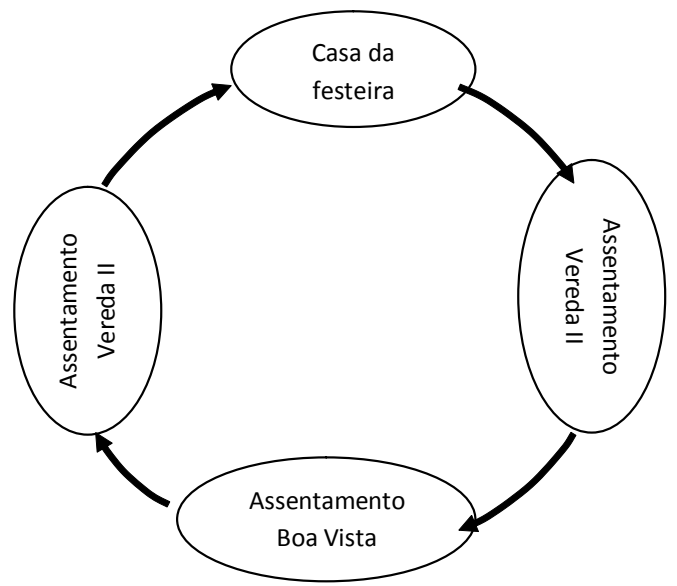

Figura 3: Representação da folia do Divino Espírito Santo na região Pé de Serra

eu acho que esse ano deve vir umas 400 pessoas, que comem, dançam até o dia raiar (festeira, assentamento Vereda II, 2006).

Além disso, os foliões relataram que a folia representa momento de integração entre católicos e não católicos e também entre pessoas de outros assentamentos e da cidade, que no final de semana da folia vão para o assentamento em que ela se realiza.

A chegada da folia na casa da festeira é um dos momentos mais importantes do cortejo: recebida com foguetes e cantoria, e o alferes ondula a bandeira ao vento. Esses movimentos, denominados 'venas', culminam com a saudação do povo aos foliões. Em seguida o alferes responsável por carregar a bandeira vai até a festeira dona da casa e lhe entrega a bandeira, que será hasteada. Momento de grande emoção - o hasteamento da bandeira e a soltura de uma pomba branca que simboliza o Divino -, em que os devotos agradecem ao santo as graças alcançadas.

Em seguida os foliões convidam os devotos a dançar com eles a catira, dando início à segunda fase da festa, que é dedicada à confraternização de foliões, devotos e convidados.

A catira é dançada em círculo formado por pares que ao som das violas palmeiam e batem pés alternadamente, em evoluções variadas, de entremeio ao canto da moda, dançando logo a seguir o recortado (sapateado). O ritmo é diferente a cada coreografia - os diferentes contatos dos pés com o solo, por exemplo, imprimem uma quantidade de esforço que traz uma riqueza de significados expressivos, distintos e perceptíveis em cada etapa da dança. Esse bater dos pés ou sapatear liga o homem à terra, dura, rachada, que dialoga com o homem e suas crenças.

Segundo Rodrigues (1997), assim como os pés, os movimentos das mãos utilizam uma gama de possibilidades próprias dessa parte do corpo. A função das mãos nessa dança é de propulsora do diálogo entre as partes do corpo mãos e pés, ou seja, o ba- 
ter das palmas das mãos fortalece e dialoga ao mesmo tempo com a ação expressiva do bater dos pés no chão. Nesse sentido, as apresentações dos catireiros começam com a saudação dos violeiros e cantadores, que em roda ou fileiras, entoam os cantos de catira e da roda com coreografias simples ao som de viola, pandeiro, palmeado e sapateado. As letras das 'modas' revelam o comportamento, conforme herança de conhecimentos transmitidos pelas gerações anteriores, a atitude do homem diante de um fato, de uma pessoa ou em defesa da natureza.

Os catireiros cantam suas crenças, homenageiam o Divino Espírito Santo, lembram parábolas bíblicas, normas morais e sociais, o trabalho e também sátiras. Nos versos da catira imperam a crítica social, a religiosidade, a reforma agrária, a vida no assentamento e as preocupações ecológicas. A marca do toque do pandeiro e a batida da viola no compasso dos pés dão a tônica dessa dança.

Logo após a catira e antes de iniciar o baile que encerra a festa, todos os presentes vão para o redor da mesa de jantar, rezam e agradecem ao Divino Espírito Santo mais um ano com saúde e fartura. Depois dessa celebração inicia-se o jantar e a festa se encerra com forró, música eletrônica e um bingo que dura a noite toda. Nesse sentido, é possível perceber que sagrado e profano andam de mãos dadas nessas celebrações.

Esse tipo de festejo é importante para agregação tanto dos moradores dos assentamentos quanto dos visitantes: foi possível perceber que durante o baile assentados de todos os credos se juntam e participam, bem como os moradores da cidade, que normalmente são parentes das famílias assentadas. Esse momento profano pode ser considerado o ponto principal de interseção das famílias participantes da festa.

\section{AS FESTAS DE SANTO E A DANÇA DO MARABAIXO EM COMUNIDADES QUILOMBOLAS NA REGIÃO DO ESTADO DO AMAPÁ}

Essa seção apresenta alguns festejos do catolicismo tradicional, resultado de pesquisa realizada em comunidades tradicionais (quilombolas e extrativistas) encontradas às margens da BR-156, que liga o sul do Estado do Amapá à capital, Macapá.

Durante os trabalhos de campo foi possível apreender que os festejos são heranças trazidas pelos missionários católicos e pelos escravos vindos da África Central, que chegaram à região sobretudo a partir do século XVIII, por volta de 1770. Na ocasião, fato histórico marcante na região foi a chegada de cerca 163 famílias de colonos portugueses e seus escravos da costa africana. Esses colonizadores vieram para a região em decorrência de conflitos entre portugueses e muçulmanos, e isso contribuiu para o início da ocupação das áreas que atualmente correspondem aos municípios de Mazagão Velho e Macapá, próximos da foz do rio Amazonas, no Estado do Amapá (OLIVEIRA, 1999).

Destarte, os principais festejos dessa região são os que emanam do catolicismo popular:

aqui sempre tem festa de santo, quando não é nessa comunidade é na outra; assim, uma comunidade vai convidando para participar das festas na vila do 
outro. As festas do padroeiro é muito animada aqui na reserva [Resex do rio Cajari] (entrevistado em Vila de Santa Clara, 2007).

Os santos de devoção local podem ser são José, são Mateus, são Sebastião, são Tiago, são Benedito, o Divino Espírito Santo, Nossa Senhora de Fátima, são Pedro, entre outros. No caso de são Tiago, os moradores do município de Mazagão explicam que a comemoração, na segunda quinzena de julho, tem conotação diferente, pois simula a vitória dos cristãos contra os mouros nas lutas travadas no continente negro.

A relação com o santo padroeiro é tão importante, que em muitos casos as comunidades incorporam o nome do santo de devoção na denominação do grupo e/ou do lugar.

O quadro abaixo apresenta o calendário de alguns santos padroeiros encontrados nas comunidades localizadas nas proximidades da BR-156 no Estado do Amapá.

\begin{tabular}{|l|}
\hline $\begin{array}{l}\text { QUADRO 1. FESTAS DE SANTOS DEVOCIONÁRIOS NA REGIÃO DA BR-156 ENTRE } \\
\text { OS MUNICÍPIOS DE LARANJAL DO JARI E MACAPÁ, NO ESTADO DO AMAPÁ }\end{array}$ \\
\hline Festa de santo rei \\
\hline São Gonçalo \\
\hline São Sebastião \\
\hline São Brás \\
\hline São Benedito \\
\hline Nossa Senhora da Piedade \\
\hline Divino Espírito Santo \\
\hline Nossa Senhora da Nazaré \\
\hline São Tiago \\
\hline Nossa Senhora da Conceição \\
\hline Nossa Senhora de Fátima \\
\hline São Pedro \\
\hline Santa Clara \\
\hline Festa de Santana \\
\hline Festejos em louvor à Mãe de Deus \\
\hline
\end{tabular}

Para organização dessas festas, normalmente, é eleita uma comissão coordenadora constituída por moradores de ambos os sexos que ficam responsáveis pelo bom andamento dos preparativos, neles incluída a arrecadação de donativos que serão sorteados nos bingos; essas doações costumam estar relacionadas ao pagamento de promessas feitas visando obter a proteção da família, a cura de alguma doença ou até melhores colheitas. 
Oliveira (1999), estudando festejos semelhantes na cidade de Macapá, aponta que existe toda uma logística para organizar as festas, com um rodízio entre as famílias encarregadas das tarefas necessárias antes, durante e depois do festejo. Normalmente, esse rodízio está relacionado a acordos estabelecidos por aqueles que mantêm a devoção aos santos e a tradição do evento religioso.

Ainda segundo a autora essa seria característica relevante de comunidades que vivem na Amazônia, que passam grande parte do ano envolvidas com os preparativos desses festejos, constituídos por expressões de fé, de agradecimento e renovação dos pedidos dessas comunidades a seus padroeiros.

Na casa onde acontece o marabaixo é construído um grande pátio com bancos ao redor, que se prolonga da sua porta principal ao meio-fio da rua. Tal espaço é destinado aos fazeres profanos e ao marabaixo. Ou seja, onde se dança nos dias de marabaixo, bem como nos dias destinados aos bailes populares. Corresponde ao espaço público daquela realização comunitária (OLIVEIRA, 1999:5)

A estrutura da festa conta com diversos atores: labardistas, alferes da bandeira, mestre-sala, carregadores da bandeira, tocadores e tamboreiros, entre eles.

De acordo com as famílias entrevistadas, geralmente a festa se inicia pela manhã com queima de fogos e missa celebrada por padres vindos da cidade. Durante o dia a imagem do santo percorre as casas da comunidade, em cortejos que são acompanhados pelos devotos entoando ladainha e versos. À noite acontecem ladainhas, bingos e, em algumas festas, hasteamento da bandeira. No final desses ritos é servido o jantar ou o lanche e depois segue-se a festa profana que pode ser animada por forró e por música com estilo 'tecnobrega', sendo também entoados os tambores de batuque acompanhando as danças regionais, principalmente o marabaixo.

Trata-se de um tipo de dança folclórica que transmite sentimentos de tristeza, alegria, fé e esperança, tendo como referência as raízes culturais de origem africana. Está presente em muitas festas do catolicismo tradicional das comunidades negras do Estado do Amapá, sobretudo nos municípios de Macapá, Santana e Mazagão, sendo, portanto, dança fundamental para os amapaenses.

Num misto de manifestação religiosa espontânea do povo, nem sempre bem interpretada, e originalidade dos passos ao som dos tambores, a dança africana ali se implanta, com base na agilidade dos pés. Cada integrante escolhe a roupa a seu gosto e

3 Diocese de Macapá. Disponivel em: www.diocesedemacapa.com.br/ festas_marabaixo.php. Acesso em 16 de maio de 2010. dança de pés descalços, mas são aspectos característicos dos trajes anágua rendada, roupa bem larga e rodada, toalha, brincos e um raminho de flor na cabeça. Os homens usam chapéu de carnaúba enfeitado com flor e fita, toalha grande aberta, camisa e calça a gosto. Assim os passos do marabaixo, sempre arrastando os pés descalços, deslizam no chão, ao som de caixas cobertas de couro, que alguns denominam tambor. ${ }^{3}$ 


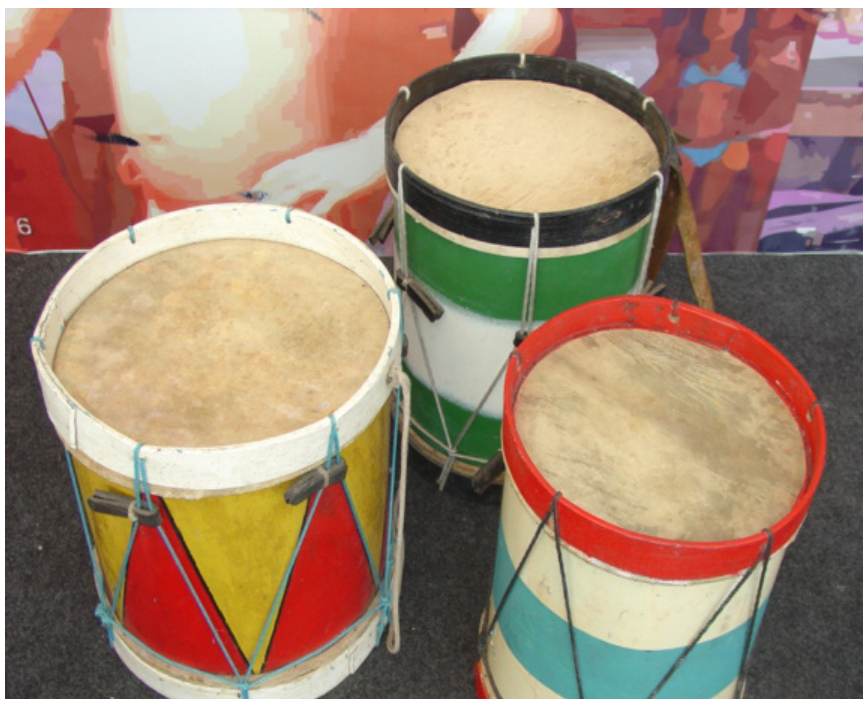

Figura 4. Tambores usados na festa do marabaixo Foto: Marcelo Leles Romarco de Oliveira

Os festejos do Divino Espírito Santo, de são Benedito, são Tiago e da Santíssima Trindade são os principais de algumas comunidades que interpretam o marabaixo.

Nesse sentido, Oliveira (1999) descreve o marabaixo como prática de orientação religiosa seguida pelas populações negras e por remanescentes quilombolas amapaenses que expressam sua fé através da dança e do canto acompanhados por tambores, sendo frequente o consumo de gengibirra (bebida alcoólica), na parte da festa, digamos, profana, posto que a manifestação é marcada por dois grandes momentos, um relacionado ao aspecto religioso e outro relacionado aos bailes populares, como atesta o autor.

O marabaixo consiste em uma reunião de práticas religiosas e profanas de iniciativa popular, que não têm nada a ver com os cultos católicos eclesiásticos, que o caracteriza enquanto catolicismo popular (...) Acontece em louvor à Santíssima Trindade e [ao] Divino Espírito Santo nos bairros da Favela e Laguinho no Centro da cidade de Macapá, em louvor à Santa Maria no Curiaú e nas várias outras comunidades como parte dos festejos a outros santos, em momentos distintos (OLIVEIRA, 1999: 2-3).

Assim, o marabaixo é significativo componente da identidade social e etnicidade de grupos sociais amapaenses, permeado de múltiplos significados, históricos, sociais e religiosos, e, por isso, considerado símbolo do Estado do Amapá. Seu ritmo vincula-se às tradições musicais, culturais e históricas elaboradas a partir das referências do catolicismo popular e das crenças dos praticantes.

Buscando entender a importância do marabaixo junto a essas comunidades, os autores entrevistaram um grupo da cidade de Mazagão e outro no quilombo do Torrão do Matapi. Nesses depoimentos, os grupos explicaram que uma das conotações dessa manifestação está relacionada à vinda de seus descendentes da África Ocidental para o 
Brasil, aludindo ao trajeto a que foram submetidos. Outra explicação que ajuda a entender o marabaixo é o marabati, termo árabe que significa saudar os deuses.

Oliveira (1999) considera a palavra uma possível variação de marabuto ou marabut, do árabe morabit (sacerdote malê), sendo a manifestação fragmento de um ritual malê, do grande império afro-sudanês do século XVI.

As caixas usadas no marabaixo são construídas com tronco de árvores e pele de animais (Figura 4), e as mãos dos homens nas caixas (em geral três) determinam o ritmo dos pés das mulheres, que se arrastam no salão. A coreografia, como a maior parte das danças afro-brasileira é circular (deixando no centro os tocadores das caixas) e em sentido anti-horário. "A dança imitaria os passos dos negros e escravos com os pés presos por correntes (...) uma de nós puxa os versos que as outras que estão dançando e fazem coro e cantam as trovas" (grupo folclórico de Mazagão Velho, 2007).

Assim como no caso da festa do Divino Espírito Santo realizada na região Pé de Serra, em que a festeira cede sua casa para as cerimônias, os devotos amapaenses também oferecem suas casas para a celebração da festa. Essa situação foi observada nas comunidades de remanescentes de quilombo de Campina Grande e Torrão do Matapi, localizados à beira da BR-156 no município de Macapá. É importante destacar que em algumas comunidades existem espaços comunitários em que a festa pode acontecer.

Segundo Oliveira (1999) a oferta da casa do devoto representa obediência e renovação do culto às imagens, pois a quebra desse contrato com o santo de devoção poderá significar a retirada da proteção ou da graça alcançada.

Uma das características desses festejos comemorados com o marabaixo é a animação da celebração, da dança, sempre em meio a sorrisos e alegria. As músicas cantam em versos as façanhas das comunidades, suas lendas, seus valores culturais, suas tradições e suas vitórias.

Destarte, os ritos, o ritmo das caixas (tambores), o ladrão (músicas e trovas populares dos próprios devotos) e os bailados do marabaixo dizem respeito ao modo de viver das comunidades, suas formas de expressões e suas identidades, além da manifestação ser considerada instrumento de valores éticos, de protesto e de contestação das comunidades negras no Estado do Amapá.

\section{CONSIDERAÇÕES FINAIS}

Por meio deste texto apresentamos a importância dos festejos religiosos em comunidades rurais no interior do Brasil, manifestações que, apesar da modernidade, persistem como importante ponto de interseção na vida dessas populações, cujo cotidiano é perpassado por valores tradicionais e saber que envolve os ciclos naturais, a fé e as manifestações culturais. Esses festejos são uma forma de comunhão e transferência de saberes e valores para os membros da comunidade. 
No caso dos assentamentos estudados a festa do Divino Espírito Santo foi uma forma encontrada por alguns membros para resgatar tradições adormecidas e restabelecê-las.

Nesse novo espaço, novas formas de socialização, novos saberes adquiridos, foram acumulados ao longo de suas trajetórias de vida, podendo ser reproduzidos nesse ambiente. Portanto, eventos dessa natureza contribuem para que as famílias assentadas, sobretudo as de orientação católica, desenvolvam coesão e identidade cultural de grupo.

No caso das famílias descendentes de escravos, esses festejos, sobretudo o marabaixo, representam uma forma de resistência à modernidade e uma maneira de preservar e manter suas identidades sociais e culturais - de fato, o marabaixo é considerado uma das mais fortes expressões da cultura amapaense, sobretudo, dos remanescentes de quilombolas.

Acreditamos que esses festejos, nessas regiões, contribuem para reavivar memórias e estreitar laços, mediante elementos simbólicos e culturais revelados nos encontros, danças, cantos e crenças, aproximando cada guardião, festeira, labardista, alferes, mestre-sala, tocador e devoto e exaltando a excelência das relações humanas, o convívio social e o sentimento de pertencimento a um grupo.

\section{REFERÊNCIAS BIBLIOGRÁFICAS}

BRANDÃO, Carlos Rodrigues. Os sacerdotes da viola. Petrópolis: Vozes, 1980.

. Plantar, colher e comer. Rio de Janeiro: Edições Graal, 1981.

CANDIDO, Antonio. Os parceiros do Rio Bonito: estudo sobre o caipira paulista e a transformação dos seus meios de vida. São Paulo: Livraria Duas Cidades, 1987.

FERLINI, Vera Lúcia do Amaral. Folguedos, feiras e feriados: aspectos socioeconômicos das festas no mundo dos engenhos. Festa: cultura \& cociabilidade na América Portuguesa, volume II. István Jancsó, Iris Kantor (orgs.). São Paulo: Hucitec/Edusp/Fapesp/Imprensa Oficial. Coleção Estante USP - Brasil 500 anos, v.3). 2001.

GAETA, Maria Aparecida Junqueira Veiga. A Cultura clerical e a folia popular. Revista Brasileira de História, v. 17, n. 34. São Paulo, 1997.

GARAUDY, Roger. Dançar a vida. Rio de Janeiro: Nova Fronteira, 1980.

GUARALDO, Tamara de Souza Brandão. A apropriação de elementos tradicionais caipiras: o caso de Dois Córregos-SP. Disponível em: http://encipecom.metodista.br/ pdf. Acesso em 16 de maio de 2010.

MAUSS, Marcel. Ensaio sobre a dádiva. In: Sociologia e antropologia. São Paulo: Cosac e Naify. 2003: 184-317.

OLIVEIRA, Marcelo Leles Romarco. Retratos de assentamentos: um estudo de caso em assentamentos rurais formados por migrantes na região do entorno do Distrito Federal. Tese de Doutorado em Ciências, Universidade Federal Rural do Rio de Janeiro, UFRRJCPDA, Rio de Janeiro-RJ, 2007.

OLIVEIRA, Maria do Socorro dos Santos. Religiosidade popular em comunidades estuarinas amazônicas: um estudo preliminar do marabaixo no Amapá. In Scripta Nova Revista Electrónica de Geografía y Ciências Sociales. Universidad de Barcelona. N. 45 
(49), ago. 1999. Disponível em http://www.ub.es/geocrit/sn-45-49.htm. Acesso em maio de 2010.

OLIVEIRA, Roberto Cardoso. O trabalho do antropólogo. São Paulo: Unesp. 2000.

PRADO, Regina de Paula. Todo ano tem: as festas na estrutura social camponesa. Dissertação de Mestrado em Antropologia Social, Universidade Federal do Rio de Janeiro, UFRJ-Museu Nacional, Rio de Janeiro-RJ, 1977.

RODRIGUES, Graziela Rodrigues. Bailarino pesquisador intérprete. Processo de formação. Rio de Janeiro: Funarte, 1997.

SARAIVA, Adriano Lopes. SILVA, Josué da Costa. Espacialidade das festas religiosas em comunidades ribeirinhas de Porto Velho, Rondônia. In revista Espaço e Cultura, Uerj, Rio de Janeiro. n. 24, jul/dez de 2008: 7-18.

Marcelo Leles Romarco de Oliveira é doutor em Ciências, Desenvolvimento, Agricultura e Sociedade (CPDA/UFRRJ) e professor efetivo do Departamento de Gestão, do Instituto Federal de Educação, Ciência e Tecnologia - Sudeste de Minas Gerais - Campus Rio Pomba.

Evanize Kelli Siviero Romarco é mestre em Pedagogia da Motricidade Humana (Unesp - Rio Claro) e professora-assistente do curso de Dança, do Departamento de Artes e Humanidades da Universidade Federal de Viçosa - MG. 